\title{
Caledon Meeting of the South African Association for the Advancement of Science.
}

THE twenty-eighth annual meeting of the South African Association for the Advancement of Science was held at Caledon on July $7-12,1930$, under the presidency of Mr. H. E. Wood, Union Astronomer. The meeting was well attended and eighty-two papers were read. The South Africa Medal and grant were presented to Dr. A. L. du Toit at the close of the presidential address. A popular illustrated lecture was given by Dr. G. H. Skaife on heredity. There was a reception by the Mayor and councillors and visits to various places of interest in the neighbourhood.

The presidential address by Mr. H. E. Wood was entitled "Recent Astronomical Developments". In it he pointed out that astronomical observatories throughout the world are about to combine to redetermine the mean distance of the sun from the earth, the unit in terms of which all astronomical distances are measured. This is being undertaken now because the minor planet No. 433, Eros, makes a near approach to the earth early in 1931. Mr. Wood also indicated that in many cases he enumerated, while the actual object has not been attained, many other highly important astronomical discoveries have resulted. Problems of the determination of the distances of the stars were discussed and the various methods compared. The constitution of interstellar space in the light of recent work was described. Recent advances in knowledge of the nature of light and Millikan's work on high frequency radiation were noted. The address elosed with a review of man's conception of the universe at various stages of his history.

The presidential address to Section $\mathbf{A}$ was delivered by Prof. H. H. Paine, who dealt with "The Motion of Ions and Colloid Particles in an Electric Field". The alliance of physics, chemistry, and mathematics was indicated, with a possible extension to biology. Research in electrical specific conductivity of solutions was discussed, as were the possible effects of neighbouring ions on each other's mobilities. The rôle of the ionic atmosphere and the work of Debye and Hückel were set forth. Onsager's work, eliminating the use of Stokes's law for the movement of ions, and the Brownian movement of ions were discussed. Evidence was given from personal work that the initial rise in mobility so often observed is due to the residual electrolyte impurities in a colloidal solution. The analogy between ions and colloidal particles, so far as their electrical structures are concerned, was the chief argument of the address.

Prof. W. F. Barker chose "Some Effects of Light" as his presidential address to Section B. He first set forth the relationships of the various kinds of radiation and the effect of the excited atom or molecule. Photochemical processes were discussed in relation to photography, vision, and carbon assimilation in plants. The photochemical association in rhodopsin was briefly outlined. The far-reaching importance of photosynthesis of plants was indicated. The synthesis of sugars by plants and the decomposition products of activated carbonic acid, especially the possible intermediate production of formaldehyde, were discussed. The work of Baly, Porter, and Ramsperger was analysed and the importance of surface reactions indicated. The reactions of activated formaldehyde with simple inorganic nitrogenous compounds, with the synthesis of proteins in the daytime and their transport at night, probably as asparagine, were discussed. The nitrate supply as the limiting factor in the synthesis of proteins in plants and the practical application to the fertiliser problem were indicated. The chemistry of chlorophyll and vitamins was described and also the effects of ultra-violet light on living organisms.

The president of Section C, Dr. E. P. Phillips, gave "A Brief Historical Sketch of the Development of Botanical Science in South Africa and the Contribution of South Africa to Botany" as his address. It comprised a review of botanical progress over two hundred and fifty years. Three periods were set forth. The first commenced with the early botanical collectors from the Cape, to the time of W. H. Harvey and his "Genera of South African Plants". At the close of this period, about 1868, the first South African botanists appeared, and the second period, ending about 1903, was marked first by quiescence and then by renewed activity. The third period, from 1903, marked the development of botanical science in the universities. The collectors, botanical literature, and trends of each period were detailed. The first period was marked by much taxonomic work and at its end by publications. The second period saw great extension of this work, and the influence of Bolus at the Cape and of Medley Wood in Natal was marked. The activities of many other collectors were detailed and the vast amount of work on systematic botany and plant geography indicated. The third period, from 1903 onwards, was marked by university developments, plant biology studies, economic botany in many phases, plant embryology, and the institution of the Union Botanical Survey.

"Some Aspects of Bird Life" was chosen by Dr. E. L. Gill as his presidential address to Section D. Adaptations were discussed. It was pointed out that the reaction against adaptation to environment has almost certainly overshot the mark, though correlation of structure and way of life are not necessarily close. Wading birds were discussed in relation to their feeding habits, bills, and legs. The avocet's turned-up bill "may be the result of sorne phase of racial pathology perhaps not just disastrous enough to lead to the extinction of the stock". Plumage and its relation to flight were also discussed. The subject of subspecies and races of birds was intro. duced and the time-factor for the development of subspecies indicated with reference to Moreau's work on crested larks in Egypt. Bird behaviour and patterns of behaviour in courting, play, and leisure were noted, and migration of birds as affecting South Africa discussed. South Africa has few islands and on the mainland dispersal is rapid. South Africa is the terminus for the great migrations from the far north. Great numbers of European birds winter at the Cape, and many African birds come to breed and then return to tropical Africa for the southern winter. The movements of the purely African birds are still largely a mystery. The birds of the Southern Ocean need more investigationa matter of difficulty. The physiological effect of migration and the unknown stimulus that moves birds to such unaccustomed feats of endurance were also mentioned.

The subject of "South Africa's Place in Prehistory: A Plea for Organised Research and the Better Preservation of Historic Remains ", formed the presidential address to Section $\mathrm{E}$ given by $\mathrm{Mr}$. C. van Riet Lowe. The early history of archæology was briefly reviewed, the South African work dating roughly from Dale, 1866, since when a number of workers have appeared. The reasons for differences in nomenclature in South African and European cultures were detailed, and also the relationship of European and African Stone Ages. The importance 
of geology and geography in relation to ethnology was stressed. Various aspects of African prehistoric art were detailed and stress laid on the value of rock engravings or petroglyphs, the evolution of numerous styles and four probable successive phases being outlined. The need of correlation of all associations and of detailed search for such associations was urged. The address concluded with an appeal for greater study and better preservation of archæological objects.

"Some Problems of the Transition from Subsistence to Money Economy" was the subject of the presidential address of Mrs. M. Palmer to Section F. The transition is inevitable and many South African natives are now in the transition stage. The conservatism of subsistence economy is because of its guidance by customs and absence of markets, competition, and profits; and communal tenure of land is correlated with such economy. The social and economic reactions to be expected under the extremely rapid transition in the African and eastern areas of the world were discussed. Private ownership of land has caused misunderstandings repeatedly among primitive peoples and the commercial use of land is incomprehensible to them. The widely divergent accounts of the economic position of the native were explained. Even when individual peasant tenancies are established, an unemployment problem appears in the second generation. Commercial agriculture requires commercial development to balance it. The teaching of primitive crafts by out-of-date means to natives was deplored, for it gives them false ideas of successful livelihood that cannot materialise in competition with machinery. Artificial means of inducing natives to take up wage-labour have been necessary, and taxation and organised recruiting have supplied these. At first the native, who only works in town about half the year, separated from his land and family, regards wages as tax money or as a means to luxury. Later, as his needs increase, subsistence in the reserve largely disappears and his town wages are his real support. Under such conditions, undercultivation of the reserves, inefficient and casual labour, a lessened market for the products of industry, and numerous evils due to lack of supervision and separation of families result. The system of 'native treasuries' and of co-operative credit societies was explained and recommended as a great aid in bridging this transition period.

In Section A, meteorological work in the Transvaal and in Mozambique was described. The effects of oil on the coefficient of restitution and the electrical field of the atmosphere are of interest to physicists ; astronomers dealt with the origin of meteorites and the apparent orbit of a spectroscopic binary. A new method of deducing borehole capacity was propounded; and the veteran mathematician, Sir Thomas Muir, made his tenth contribution to the bibliography of determinants.

In Section B, soil chemistry in connexion with the potash requirements of South African soils, base exchange in the Malmesbury shale series, soil acidity, sticky point water, and hard pan formation produced a number of papers. Slangbos oils and the antimony electrode were discussed. The state of natural water supply and the effect of destruction of vegetal cover received serious consideration, as did also a paper on the medicinal waters of South Africa in international measurements.

In Section C, systematic work on the Virosæ division of the Euphorbiaceæ, on new Liliaceæ, Hydrocharitaceæ, Dianthaceæ, and Lobostemon was detailed by various workers. Economic botany was represented by work on barley diseases, South African fungi, root nodules, abnormalities in the composition of oranges and seed formation in pears, and effects of fire on biotic communities. Ecological work dealt with 'Gifblaar' (a stock poison), flora of a lamsiekte farm, bush groups, and floras of individual areas. The physiological side was represented by work on hydrolysis in the vine and the influence of soil water around roots on the hydrogen ion concentration of tracheal sap.

In Section D a number of interesting topics were discussed. A series of papers by members of the University of Stellenbosch dealt with Amphibian osteology, osteogeny, and ontogenesis in regard to various forms, including Heleophryne, and there was discussion of Noble's dictum in relation to the latter form. Ecological notes were given on the Acridiidæ of the Cape Peninsula. Seasonal variation in the coat of common domestic mammals and density in variation of the fleece of the merino are of economic importance. Animal ecologists also dealt with the methods of studying numbers of terrestrial animals and numbers of tsetse fly in Tanganyika Territory. A modification of the rapid agglutination test, of use to the veterinary profession, was set forth. Descriptions were given of a number of new species of Protozoa, including new and economically important Myxosporidia of fish and new Protoopalinidæ. Cases of physical inheritance and of racial admixture, including Chinese crosses with various natives and Indians, were described. Variations in the skulls of vervet monkeys, ovine schistosomiasis, and social hydrology were also discussed, and a morning was devoted to a discussion on provision for marine biology. The centenary of the death of Lamarck was commemorated.

In Section $\mathbf{E}$ a human skull was described. The chronology of the Mossel Bay industries was detailed and illustrated, as were implements found in a cave at Tafelberg Hall. Interesting accounts of cattle magic and medicines in Bechuanaland and of Bantu customs in relation to widowhood and lobola formed important contributions to social anthropology.

In Section $\mathrm{F}$, the historical side was interestingly represented by short papers on an eighteenth century MS. on agricultural improvement at the Cape and on the first leper settlement in South Africa. The psychology of mysticism and of personality were discussed, and a reasoned account of the psychological factors affecting the attitude of black to white was presented. The crisis in our present civilisation was given a fine exposition. The progress of Portuguese children in Lourenço Marques and in Portugal were compared.

The next annual meeting of the Association will be held in July 1931 at Grahamstown, under the presidency of Prof. J. W. Bews, professor of botany at the Natal University College, Pietermaritzburg, Natal.

\section{H. B. F.}

\section{University and Educational Intelligence.}

CAMrridac.-J. C. P. Miller, of Trinity College, has been elected to an additional Isaac Newton Student. ship tenable for one year.

The General Board has recommended that a readership in statistics shall be established as from Jan. 1 next, and that it should be authorised to appoint as first holder of the readership Mr. G. Udney Yule, of St. John's College. It is recommended that the readership shall be assigned primarily to the Faculty of Agriculture and Forestry.

The Faculty Board of Archæology and Anthropology has appointed C. B. Humphreys, of Christ's College, to 